\title{
A Study on Conjunctional Cohesion Errors by CSL Learners
}

\author{
Chengxin Zhao \\ Henan University, Henan, China
}

\begin{abstract}
As the world advances, more and more people begin to learn Chinese as a second language (CSL). In the course of teaching CSL, the author finds that although the senior students have a certain ability to express in Chinese, there are still various problems in their output. Among the problems, the text cohesion is one of the most prominent. Therefore, in this paper, the author analyzes the errors of CSL learners in the use of conjunctional cohesion devices, which are roughly divided into four types, namely, parallel relationship, temporal succession, causal relationship, and reversal relationship. The causes of the errors are discussed, too. Finally, the author puts forward the corresponding teaching and learning suggestions, such as teaching the learners to learn the thinking mode of Chinese, cultivating the learners' contextual concept, comparing similarities and differences between mother-tongue and Chinese, and strengthening the practical training for the learners to use cohesive devices.
\end{abstract}

Keywords: learning Chinese as second language (CSL), conjunction, cohesion, errors

\section{Introduction}

Conjunctive elements are cohesive not in themselves, but indirectly, by virtue of their specific meanings which presuppose the presence of other components in the discourse. It is generally accepted that classifying conjunction according to the semantic relationship embodied in the conjunctive elements is more scientific and reasonable. Based on the studies by Liao Qiuzhong (1992, pp. 62-89), Zhou Gang (2002, pp. 101-103), Zheng Guiyou (2002, pp. 41-44), and Zhang Bin (2002, pp. 470-493), conjunction can be roughly divided into two categories - coordinative relationship and adversative relationship, with the former to be further divided into parallel relationship and temporal succession, and the latter into causal relationship and reversal relationship (see Table 1).

Table 1

Categories and Types of Conjunction

\begin{tabular}{|c|l|l|}
\hline Category of conjunction & \multicolumn{1}{|c|}{ Type of conjunction } & \multicolumn{1}{c|}{ Sub-type of conjunction } \\
\hline \multirow{2}{*}{ Coordinative relationship } & Parallel relationship & Parallel, contrast, selection, additive/furthering, and annotation \\
\cline { 2 - 3 } & Temporal succession & Time succession, logical order, space order, and event order \\
\hline \multirow{2}{*}{ Adversative relationship } & Causal relationship & Reason, hypothesis, condition, and purpose \\
\cline { 2 - 3 } & Reversal relationship & Reversal, concession, and preference \\
\hline
\end{tabular}

It is a very general way of classification, which is helpful for our discussion. Various suggestions could be taken up for classifying the phenomena which we call conjunction. There is no single, uniquely correct inventory of the types of conjunctive relations. So, different classification is possible and the line between the above categories is by no means always clear.

Chengxin Zhao, Ph.D., professor, Graduate School, Henan University. 


\section{Conjunctional Cohesion Errors}

There are quite a few ways to classify errors. One of those is to use a surface strategy taxonomy. This highlights the ways by which surface structures are altered. Table 2 shows the error types proposed by Carl James (1998, p. 274).

Table 2

Categories of Errors

\begin{tabular}{|l|l|}
\hline \multicolumn{1}{|c|}{ Categories } & \multicolumn{1}{c|}{ Descriptions } \\
\hline Omissions & Absence of an item that must appear in a well-formed utterance. \\
\hline Additions/Over-inclusions & Presence of an item that should not appear in a well-formed utterance. \\
\hline Misselections & Use of the wrong form of a morpheme or structure. \\
\hline Misorderings & Incorrect placement of a morpheme or a group of morphemes in an utterance. \\
\hline Blends & A blend of two or more of the cases mentioned above. \\
\hline
\end{tabular}

We collected some cases of errors (a total of 163) made by Chinese as a second language (CSL) learners when they learn Chinese. The error corpus is from the compositions of CSL students at Henan University (Kaifeng, China) and Zhongshan University (Guangzhou, China) (Zhao, 2005; Zhang, 2017). In the light of the categories outlined above, the errors by CSL learners are discussed in the following sections.

\section{Error Statistics}

Altogether, we collected 163 cases of conjunctional cohesion errors. Their distribution among the four types is illustrated in Table 3.

Table 3

The Distribution of Four Types of Conjunctional Cohesion Errors

\begin{tabular}{lcc}
\hline Type of errors & Number of errors & Ratio (\%) \\
\hline Parallel relationship errors & 36 & 22.1 \\
Temporal succession errors & 20 & 12.3 \\
Causal relationship errors & 60 & 36.8 \\
Reversal relationship errors & 47 & 28.8 \\
Total & 163 & 100.0 \\
\hline
\end{tabular}

As can be seen from Table 3, the ratio of causal relationship errors is the highest, accounting for $36.8 \%$ of the total, which is more than one third. It is followed by the reversal relationship errors $(28.8 \%)$ and the parallel relationship errors $(22.1 \%)$. The lowest rate is the errors of temporal succession, which is $12.3 \%$, about one tenth of the total.

\section{Errors of Parallel Relationship by CSL Learners}

The parallel relationships in Chinese text refer to the relationship of parallel, contrast, selection, additive/furthering, and annotation.

The conjunctions used to express parallel relationship include: “. . yòu ..., “ “. . yě ...," “. .. hái ...," “...

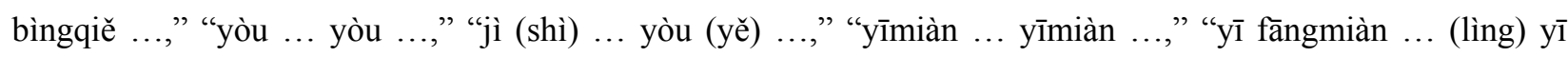
fângmiàn ...," "yībiān ... yībiān...," "yàome ... yàome ...," etc..

The conjunctions used to express contrast relationship include: “... ér ...," "shì ... bùshì ...," "bùshì ... érshì ...," etc.. 
The conjunctions used to express selection relationship include: "bùshì ... jiùshì ...," "huòzhě ... huòzhě ...," "shì ... háishì ...," etc..

The conjunctions used to express additive/furthering relationship include: "bùdàn ... érqiě ...," "bùdàn ... hái

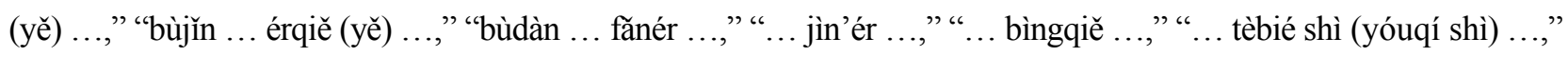

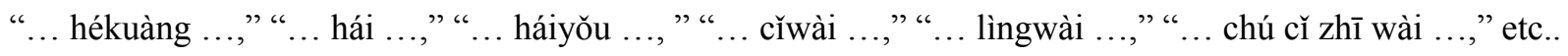

The conjunctions used to express annotation relationship include: “. . jí ...,” “... jiùshì shuō ..., " “.. yìsi shì ...," “... xiàng ...,” “... hăoxiàng ...,” etc..

The misselection of conjunctions in parallel relationship. As a conjunction, "bìngqiě" means "and," "besides," "moreover," and "furthermore." It expresses an additive/further meaning. Generally, it connects verbs and does not connect adjectives. "Yòu" means "again," "also," "as well as," and "likewise." It connects both verbs and adjectives. In the sentence as below, both "beautiful (měili)" and "sacred (shénshèng)" are adjectives. So, "yòu" is more appropriate here.

Example $1{ }^{*} J$ Jănpǔzhài shì yịgè měili bìngqiě shénshèng de difāng 。[yòu $]^{1}$

"Jì (shì) ... yòu (yě) ..." is a pair of correlatives denoting parallel relationship, which means having two aspects of the nature or circumstances. So, "yòu" should be used instead of "érqiě" here.

Example $2{ }^{*}$ Nà shíhòu jìshì zhōu rì, érqiě shì xiàwǔ liù diăn, gǔlóu guăngchăng de rén fêicháng duō。 [yòu]

"Hái yǒu" means "in addition to this" and "érqiê" is a conjunction denoting additive or furthering. In the example as below, the second clause has the meaning of "furthering," so "érqiě" should be used.

Example $3^{*}$ Zài chéngshì shēnghuó zhăo gōngzuò bǐjiào róngyì, hái yǒu jiāotōng hěn fāngbiàn。 [érqiě]

The omission of conjunction in parallel relationship. "Bùjǐn ... érqiě (hái) ..." is a pair of correlatives connecting two clauses, none of which can be used alone. What is more, in addition to the meaning of the first clause, there is another layer of meaning in the second clause. So, we should add "érqiě/hái" to go with "bùjǐn."

Example 4 *Rúguǒ bù zhùyì shuǐwēn, bùjǐn róngyì yǐnqǐ yáyín chūxiě, ( ) huì zhíjiē yǐngxiăng yáchǐ de shòumìng 。 [erqiě/hái $]^{2}$

"Chúle" denotes "besides the known" and "more is coming." It is always echoed by "hái (yò)" or "yě" in the succeeding clause. In the example as below, the learner only uses one of the correlatives "chúle," he/she misses another correlative "hái."

Example 5 *Shuǐ dēngjié de shíhòu, rénmen chúle zuò shuǐdēng, ( ) xǐhuān zài shuǐdēng lǐ fàng yīxiē dōngxī。 [hái]

The addition of conjunctions in parallel relationship. "Yě" means "also," "too," "as well as," and "as well." It emphasizes "being similar" or "same," while "hái" emphasizes "expansion." "White Temple" is a famous temple of Chiang Rai and "Black Temple" is another famous temple of Chiang Rai. So, the second clause denotes the expansion of the range of temple. Thus, "hái" should be used here and "yě" is redundant. This kind of errors is usually made by the beginners, for their Chinese proficiency is low.

\footnotetext{
${ }^{1}$ In this paper, the "*”" indicates that this is a text with error(s). The part underlined is where the error is diagnosed. The part in the square brackets is the correct form or the description of the error suggested by the author.

${ }_{2}$ In this paper, the empty parentheses in the examples indicate some morpheme(s) is (are) missed. The morpheme(s) in the square brackets after the text concerned is the correct form suggested by the author.
} 
Example 6 "Qīng lái yǒu zhùmíng de bái miào, yě hái yǒu wénmíng de hēi miào。 [“yě” is redundant]

In the text as below, "bùdàn ... érqiě ..." is used as a pair of correlatives. Evidently, "yě" is redundant here.

Example 7 "Zhōngguó bùdàn shì xuéxí hànyŭ de difāng, érqiě yě shì wǒ chéngzhăng de diłāng。 [“érqiě" or "yě" is redundant]

The misordering of conjunctions in parallel relationship. "Bùdàn ... érqiě ..." is a pair of correlatives denoting the additive/furthering relationship between the two clauses. When the subjects of the two clauses are the same, the two correlatives should be after the subject (usually with the second subject omitted). When the subjects are different, the two correlatives are placed before the two subjects respectively. In the example as below, the two subjects are different, so the two correlatives should be placed before the subjects. Thereby, "bùdàn" should be before "Měilín."

Example 8 *Wǒmen bān Měilín bùdàn huì chànggē, érqiě Píngpíng yě huì chànggē。 [incorrect placement of "bùdàn”]

"Bùjīn ... hái ..." denoting the relationship of addition or juxtaposition are generally used before predicate verbs. In the example as below, "bùjǐn" is after the predicate verb.

Example 9 *Xiăng yào xuéhăo yǔyán, xuéxí bùjūn yǔyán běnshēn, hái yào xuéxí lìshǐ, wénhuà děng。 [incorrect placement of "bùjǐn”]

The correct sentence should be:

Xiăng yào xuéhăo yǔyán, bùjǐn xuéxí yǔyán běnshēn, hái yào xuéxí lìshǐ, wénhuà děng。

The blends of conjunctions in parallel relationship. When reading the text as below, a reader may have difficulty in understanding the logical relationship between the second clause initiated by "Kěshı" and the third clause-Suǒyir. Here is a blend of three kinds of relationship: First one is between the first two clauses, the second one is between the last two clauses, and the third one is between the first two and the later two clauses. The conjunctions in the second clause and the third one are incorrect.

Example 10 "Lăonăinai qiè táozi de shíhòu, cóng lǐmiàn chūlái yīgè xiăo háizi。 Kěshì tāmen yàole zhège háizi. Suǒyǐ juédìng zìjǐ péiyăng háizi。

The text should be revised as the following:

Lăonăinai qiè táozi de shíhòu, cóng lǐmiàn chūlái yīgè xiăo háizi。Tāmen yàole zhège háizi, bìngqiě juédìng zìjǐ péiyăng háizi。

\section{Errors of Temporal Succession by CSL Learners}

The temporal succession in Chinese text refers to the fact that there exists order among language units, such as the order of time, the order of the logic, the order of the space, the order of events, etc..

Time succession is commonly expressed through the conjunctions, such as "kāishǐ de shíhòu ...,"

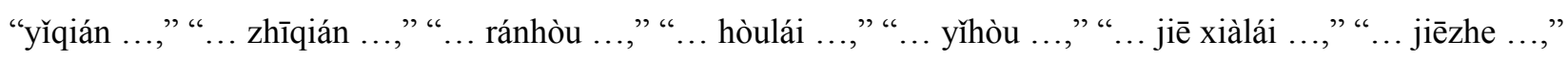
“... shāohòu ...," " ... bùjiǔ ...," etc.. 
Logical order is commonly expressed through the conjunctions, such as "shǒuxiān, ... qícì, ... zàicì, ...

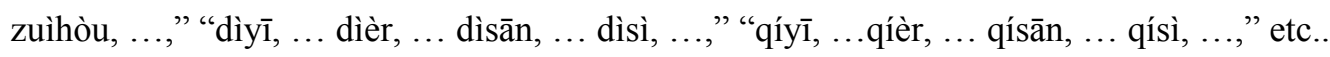

The order of events is commonly expressed through the conjunctions, such as " ... jiù ...," "... yúshì ...," “... biàn ....," etc..

The spatial order does not use conjunctions often, but some nouns of locality can be used to indicate spatial location. These nouns of locality play some functions of spatial order, such as "qiánmiàn," "hòumiàn," "shàngmiàn," "xiàmiàn," "pángbiān," etc.. For example,

Example 11 *Yáoyuăn de tiānkōng, yǒu yīgè wān wān de yuèliàng, wān wān de yuèliàng xiàmiàn shì nà wān wān de xiăo qiáo, xiăo qiáo de pángbiān shì yītiáo wān wān de xiăochuán。

The misselection of conjunctions in temporal succession. "Ránhòu" means "then, after that, or afterwards." It is a conjunction to show that one event happens after another, emphasizing the short interval between the two events. From the example as below, we can see that the interval of the two events is long instead of being short. So, "ránhòu" should be changed to "hòulái" here.

Example $12^{*}$ Gāng kāishǐ hé bié de guójiā de liúxuéshēng yīqǔ zhù de shíhòu, wǒ fāxiàn wǒmen xìnggé, xíguàn děng hěn bù yīyàng, nánmiăn huì yǒu mócā, kěshì ránhòu wǒmen què chéngle hăo péngyǒu 。 [hòulái]

As discussed previously, "ránhòu" is a conjunction to show the order of events. In the example as below, the relationship between the two sentences is not a succession of time, but an adding of information. Another conjunction "érqiě" has the meaning of addition. So, "érqiě" should be used here instead of "ránhòu."

Example 13 *Wǒ dàole zhōngguó yǐhòu, duì shénme dōu bù xíguàn, yóuqí shì yǐnshí, yī chī jiù juédé hěn qíguài, bùxiăng zài chīle。 Ránhòu wǒ shì mùsīlín, bùnéng suíbiàn chī dōngxī。[Érqiě]

The omission of conjunction in temporal succession. From the sentence as below, we can see that there exists temporal succession between "păobù" and "huí sùshè." So, a conjunction should be added between the two clauses to show the order of events. We suggest adding "ránhòu" in the parentheses.

Example 14 *Měitiān xiàwǔ liù diăn wǒ dōu huì qù cāochăng păobù, păo yīgè xiǎoshí, ( ) wǒ huí sùshè xiūxí。 [ránhòu]

The action "jìshì" is followed by "xǐhuān lüyóu" immediately, thus, a conjunction showing the order of event, i.e., "jiù" should be added in the second clause.

Example $15^{*}$ Cóng wǒ jìshì qǐ, wǒ ( ) hěn xǐhuān lüyóu。 [jiù]

The addition of conjunction in temporal succession. "Shǒuxiān" is a conjunction of logic succession, which means "first" or "firstly." In the example as below, there exist conjunctions of temporal sequence, i.e., "zhīqián" and "xiànzài." So, "shǒuxiān" at the beginning of the text is redundant and should be deleted.

Example 16 "Shǒuxiān, wǒ zhīqián hěn xiăng qù zhōngguó xuéxí hànyǔ, xiànzài, wǒ yǐjīng ná dàole kǒngzǐ xuéyuàn jiăngxuéjīn, zuòwéi yīgè liúxuéshēng zài hénán dàxué guójì hàn xuéyuàn xuéxí hànyǔle 。["Shǒuxiān” is redundant]

From the text as below, we can see that her boyfriend's "sònghuā" and her "juédé hěn kāixīn" are two events happening simultaneously. As discussed in "The misselection of conjunctions in temporal succession," "ránhòu" is a conjunction to show that one event happens after another, so it is redundant here and should be deleted. 
Example 17 *Tā de nán péngyǒu sòng hěnduō huā gěi tā, ránhòu tā juédé hěn kāixīn。["Ránhòu” is redundant]

The misordering of conjunction in temporal succession. "Xiān" is a conjunction of logical succession, which means "firstly" or "before doing something else." It is usually located immediately before the predicate verb. In the example as below, "xiān" is located before the subject of the second clause. So, "xiān" has the wrong location. It should be located before the verb "ná."

Example 18 *Wǒmen nà er chīfàn de shíhòu, xiān jiāzhăng ná tāmen xiăng chī de dōngxī, ránhòu háizi cái kěyǐ ná [Incorrect placement of "xiān”]

The text should be revised as the following:

Wǒmen nà er chīfàn de shíhòu, jiāzhăng xiān ná tāmen xiăng chī de dōngxī, ránhòu háizi cái kěyǐ ná。

The blends of conjunctions in temporal succession. In the example as below, there exist several errors. Firstly, "xiān" has the wrong location, because it is placed in the front of a modal verb "yīnggāi" instead of the predicate verb "jiào." Secondly, "rúguǒ ... jiù ..." is a pair of fixed correlatives denoting hypothesis and deduction. The two correlatives always match with each other. So, in the example as below, we should add "jiù" before the third clause to match the "rúguon" in the previous clause. Thirdly, the last clause, indicating result, is a summary of the previous statement. But it lacks the conjunction of result.

Example 19 *Bǔrú zăoshang nǐ yào qù cānjiā yīgè hěn zhòngyào de miànshì, rúguǒ nǐ méiyǒu sījiā chē de huà, xiān yīnggāi jiào chē, ránhòu hái yào děng shàng jǐ fēnzhōng, hěn máfan。

The text should be revised as the following:

Bǐrú zăoshang nǐ yào qù cānjiā yīgè hěn zhòngyào de miànshì, rúguǒ nǐ méiyǒu sījiā chē de huà, jiù yīnggāi xiān jiào chē, ránhòu hái yào děng shàng jǐ fēnzhōng, suǒyǐ hěn máfan。

\section{Errors of Causal Relationship by CSL Learners}

The causal relationship in Chinese text refers in a broad sense to the relationship of cause and result as well as condition and result. It generally includes the relationship of cause and result, hypothesis and deduction, condition and result, and the relationship of purpose.

The relationship of cause and result is usually denoted through conjunctions, such as "yīnwèi ... suǒyı̌ ...,"

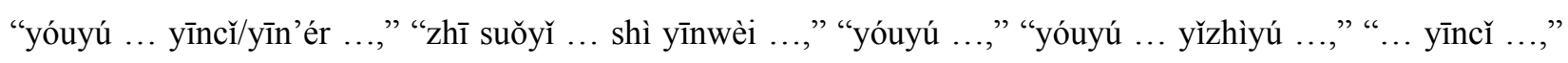
“... yīnér ...," etc..

The relationship of hypothesis and deduction is usually expressed through conjunctions, such as "rúguǒ/jiăruò/yàoshi/tăngruò/wànȳ̄ ... jiù ...," etc..

The relationship of condition and result is usually expressed through conjunctions, such as "zhy̌ǒu ... cái ...," "zhǐyào ... jiù ...," "bùguăn ... yě (dōu) ...," "wúlùn ... yě (dōu)," etc..

The relationship of purpose is usually expressed through conjunctions, such as "wèile ...," “... yǐbiàn ...," “... shěngdé ...," “... miăndé ...," etc..

The misselection of conjunction in causal relationship. "Wèile" denotes purpose. "Yīnwèi" and "yóuyú" denote reasons, with the latter indicating a reason of negative sense. In the two examples as below, both "kěyi shōu dào lǐwù" and "měiguó de lù hěn kuān" provides a kind of reason to the previous clause or the succeeding clause. So, "wèile" should be changed to "yīnwèi" and "yóuyú," respectively. 
Example 20 *Wǒ xiăoshíhòu hěn xǐhuān guò shèngdànjié, shì wèile kěyǐ shōudào lǐwù。 [yīnwèi]

Example $21^{*}$ Tã jiào tā xīn'ài de nà zhǐ gǒu zài rénxíngdào děngzhe tā. Bùliào, guò mălù de shíhòu, tā bèi gōnggòng qìchē zhuàng sǐle。 Wèile měiguó de lù hěn kuān, nà zhǐ gǒu bù zhīdào tā de zhǔrén š̌le, tā yīzhí děng hăojiǔ hăojiǔ 。 [yóuyú]

Obviously, the cause of the error in Example 21 is mother-tongue interference. In English, "for" is used to initial a clause indicating reason. And "for" is sometimes translated into Chinese as "wèile." So, the learner, whose mother-tongue is English, translates directly "for" into "wèile."

"Zhǐyǒu ... cái ..." and "zhǐyào ... jiù ..." are two sets of correlatives denoting conditions, with the former indicating necessary conditions, the latter sufficient conditions. In the example as below, the two sets of correlatives are confused. So, "zhřyǒu” should be changed into "zhǐyào."

Example $22^{*}$ Zhǐyǒu nǔlì, jiù néng qǔdé fēifán de chéngjiù [ [Zhǐyào]

"Bùguăn ... dōu ..." is a pair of correlatives denoting condition and result. So, in the example as below, "hái" should be substituted by "dōu."

Example 23 *Bùguăn wǒ duōme xiăng wǒ de qīnrén, xiăng wǒ de nán péngyǒu, wǒ hái juédé dào zhōngguó liúxué shì zhèngquè de xuănzé。[dōu]

The omission of conjunction in causal relationship. "Zh̄̄ suǒy̌r ... shì yīnwèi ..." is a pair of fixed correlatives denoting result and reason. The two correlatives always match with each other. So, in the example as below, we should add "shì yīnwèi" before the second clause to match the "zhī suǒyî" in the previous clause.

Example 24 *Wǒ zhī suǒyǐ jìngpèi kǒngž̌, ( ) tā shì yīgè yǒu dàodé de rén。 [shì yīnwèi]

"Yīnwèi ... suǒyǐ ..." is a pair of fixed correlatives denoting reason. The two correlatives always match with each other. So, in the example as below, we should add "suǒyǐ" before the second clause to match the "yīnwèi" in the previous one.

Example 25 *Yīnwèi wǒ shì yīgè hěn niánqīng de nüshēng, yě xiăng măi hăokàn de yīfú, qù lüxxíng děng děng, ( ) wǒ juédìng zhăo gè gōngzuò zhèng qián。 [suǒy̌̃]

The addition of conjunction in causal relationship. "Yīnwèi" is a conjunction denoting reason. In the example as below, the first clause does not express reason. So, "yīnwèi" here is redundant.

Example 26 * Ȳinwèi tīng shuō xuěhuā yǒu bùtóng de xíngzhuàng, liùjiăoxíng de, wǔjiăoxíng de, língxíng de, yuánxíng de ... Luòdào shǒushàng shí, hěn kuài jiù huàle, wǒ nányǐ guānchá tāmen de múyàng。 ["Yīnwèi” is redundant]

"Yīncǐ" is a conjunction of result, always used before the second clause. In the example as below, the last clause is not the result or conclusion of the previous clauses. So, "yīncǐ" here is redundant.

Example $27^{*}$ Tàiguó cài yǒu jǐ băi nián de lìshǐ, yóuyú shòu dōngxī fāng yǐnshí wénhuà de yǐngxiăng, xíngchéngle dújùtèsè de tàiguó yřnshí。 Yīncǐ, tàiguó cài yòngliào zhǔyào yǐ hăixiān, shuǐguǒ, shūcài wéi zhǔ。 [“yīncǐ” is redundant]

The misordering of conjunction in causal relationship. "Yóuyú...yīncǐ..." is a pair of correlatives denoting reason and result. When the subjects of the two clauses are different, the two correlatives should be placed before the two subjects respectively, which is the case of the example as below. Thereby, "yóuyú" should be at the beginning of the first clause. 
Example 28 *Wǒ fùmǔ yóuyú shì huáyì, yīncǐ wǒ duì zhōngguó wénhuà bǐjiào liăojiě。 [Incorrect placement of "yóuyú"]

"Yīnwèi...suǒy̌r..." is a pair of correlatives denoting reason and result. When the subjects of the two clauses are the same, the two correlatives should be placed after the subject (usually with the second subject omitted). When the subjects are different, the two correlatives should be placed before the two subjects respectively. In the example as below, for the two subjects ("Aměi" and "tāmen") are different, the two correlatives should be before the subjects. Thus, "suǒyı̌" should be located at the beginning of the second clause.

Example 29 *Yīnwèi Aměi hé nánpéngyǒu méiyǒu zhù zài yīgè chéngshì, tāmen suǒyǐ měitiān wănshàng dōu yào dă hěn cháng shíjiān de diànhuà 。 [Incorrect placement of "suǒyî̀]

The blends of conjunctions in causal relationship. In the text as below, there are three clauses which denote two kinds of relationships. The first two clauses forms a relationship of reason and result, while the first two and the third is a relationship of reason and result too, but in a higher rank.

Example 30 *Yīnwèi lüxíng de shíjiān hěn chăng, wǒ măile yìngwò de piào, suǒyǐ shuì dé tèbié hăo 。

The text should be revised as the flowing:

Yīnwèi lüxíng de shíjiān hěn zhăng, suǒyǐ wǒ măile yìngwò de piào, yīncǐ shuì dé tèbié hăo。

\section{Errors of Reversal Relationship by CSL Learners}

The reversal relationship in Chinese text refers to the semantic relationship of opposite or reverse. It includes adversative relationship, concession relationship, and preference relationship.

The adversatives usually used include: "suīrán ... dànshì ...,” “... dànshì (kěshì, rán’ér, bùguò, and què)...," “jǔnguăn ... dànshì (kěshì, bùguò, rán’ér, and háishì),” etc..

The conjunctions of concession relationship include “jíshǐ/năpà/jiùshì/gùrán/jíbiàn/zòngrán ... yě ...," etc..

The conjunctions of preference relationship include: "nìngkě ... yě ...," "yǔqí ... bùrú ...," etc..

The misselection of conjunctions in reversal relationship. "Qíshí” means "actually," "in fact," or "as a matter of fact." It denotes a logical connection that the actual situation is true after an adversative background is provided in the previous text. In the example as below, the first clause and the second are in a reversal relation, so "suīrán" should be used instead of "qíshí" for "suīrán” and "dànshi”" are correlatives which usually match with each other.

Example 31 *Qíshí wǒ yǒu hěnduō hăo péngyǒu, dàn wǒ xuănzé xiě tónglíng de péngyǒu。 [Suīrán]

"Jíshǐ" denotes the relationship of concessions. But in the example as below, the two clauses are in an adversative relationship. As mentioned below, "suīrán" and "dànshi”" are correlatives which echo with each other. So, "suīrán” should be used instead of "jíshǐ” here.

Example 32 * Jíshǐ wǒ de chē shì yīgè hěn jiù de chē, dànshì sùdù fêicháng kuài。 [Suīrán]

The conjunction "bùguăn" means "no matter" or "despite." It indicates that the results will not change in any condition or circumstances. It is usually echoed by the adverbs "yě/dōu" in the second clause. In the example as below, the first clause and the second clause are in an adversative relationship instead of a 
relationship of condition and result. So, "suīrán" should be used instead of "bùguăn" for "suīrán" and "dànshì" echo with each other to indicate adversative relationship.

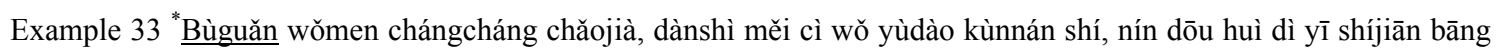
wǒ jiějué。 [Suīrán]

The omission of conjunctions in reversal relationship. Both of the two examples above denote the adversative relationship. The typical conjunction of adversative relationship is "suîrán ... dànshì ..." which constitute a pair of correlatives. In the two examples as below, both of the previous clauses lack the conjunction "suīrán" to echo "dànshì" in the following clause.

Example 34 *Suīrán dàjiā měitiān doū shuāyá, ( ) hěn shăo yǒurén zhīdào zhèngquè de shuāyá fāngfã。 [“dànshì” should be added]

Example $35^{*}$ Wǒ zài hénán dàxué xuéxí hànyǔ de shíjiān zhǐyǒu yìnián, suīrán yìnián de shíjiān hěn duăn, ( ) wǒ yīdìng huì bǎwò zhù shíjiān nǔlì xuéxí de 。 [“dànshi”" should be added]

The addition of conjunctions in reversal relationship. Because there is no adversative relationship between the sentences in the below text, "dànshi" should not be used here.

Example $36{ }^{*}$ Gēn wǒmen guójiā xiāng bǐ, kāifēng rénkǒu bǐjiào duō, wàibian yě feêicháng rènào. Dànshì, wǒ zài kāifēng zuì xǐhuān de shì kāifēng suǒyǒu de gōngyuán。 [“Dànshì” is redundant]

No adversative relationship exists between the two clauses in the example as below. So, "kěshi” should not be used.

Example 37 *Wǒ zūle yīgè fángzi, kěshì fángzi hěn dà, ȳ̄gòng 130 píngfāng mǐ。 [“kěshì" is redundant]

The misordering of conjunctions in reversal relationship. When expressing adversative relationship, "suīrán" and "dànshi”" constitute a pair of correlatives. If the two clauses concerned have the same subject, "suîrán" and "dànshì" should be placed after the subjects. If the subjects are different, "suîrán" and "dànshì" should be placed before the subjects respectively. In the two examples as below, the subjects are different, so "suīrán" and "dànshi" should be placed before the subjects respectively.

Example 38 *Suīrán wǒ yǒu yīgè gēgē, wǒmen dànshì zhăng dé yīdiănr yě bù xiàng。 [The incorrect placement of "dànshì”]

Example 39 * Suīrán tā de sùshè lí jiàoshì fēicháng jìn, zhǐyǒu sānwǔ fēnzhōng de lùchéng, tā dànshì jīngcháng chídào。 [The incorrect placement of "dànshì"]

The blends of conjunctions in reversal relationship. The below text is made up of four clauses, in which three kinds of logical relationship are put in two layers.

Example 40 *Suīrán zhǎngwò bǐjiào shăo de cíhuì liàng, zài jiăndān de gōutōng fāngmiàn méiyǒu hěn dà de wèntí, dànshì wèile hé duìfāng jìnxíng guăngfàn ér yǒu shēndù de duìhuà, bìxū shúxī gè fāngmiàn de cíhuì hé nàxiē cíhuì de zhèngquè de shǐyòng fāngfã 。

It should be revised as the following:

Suīrán zhăngwò brijiào shăo de cíhuì liàng, zài jiăndān de gōutōng fāngmiàn yě méiyǒu hěn dà de wèntí, dànshì wèile hé duìfāng jìnxíng guăngfàn ér yǒu shēndù de duìhuà, jiù bìxū shúxī gè fāngmiàn de cíhuì hé nàxiē cíhuì de zhèngquè de shǐyòng fāngfã。 


\section{A Discussion on the Causes of Conjunctional Cohesion Errors}

The reasons for conjunctional cohesion errors by CSL learners are rather complicated. The following are some of them.

\section{Low Proficiency of Chinese}

One reason is that the learners' ability to control Chinese is weak and the sense of Chinese language is poor. Rod Ellis (1994, pp. 58-61) called this factor "competence" factor, which means the learners' proficiency is low and they cannot use the target language in a normal way. As their overall language proficiency improves, these kinds of errors will gradually diminish. Chinese conjunctions are so difficult language usages that they prove to be barriers to CSL learners. Example 6 in "The addition of conjunctions in parallel relationship" is a case of this kind.

\section{Mother-Tongue Interference}

The errors caused by mother-tongue are generally referred to as interlingual errors (Ellis, 1994, pp. 58-61). From the perspective of cognitive psychology, language transfer phenomenon appeared in the process of second language learning is because of the influence of what has been acquired to what is being learned. In a sense, mother-tongue transfer can also be viewed as a strategy for the learners to acquire a second language. So, it has both negative sense and positive sense. When CSL learners acquire Chinese conjunctions, mother-tongue interference tends to be more negative than positive. Example 21 in "The misselection of conjunction in causal relationship" is a typical case of error caused by the interference of mother-tongue.

\section{The Target Language Itself}

The errors caused by the target language are generally referred to as intralingual errors (Ellis, 1994, pp. 58-61). As is the experience of many CSL learners, Chinese is a complex language which is difficult to learn. For example, Chinese has a large lexicon, many of its usages are meticulous, and some words have minute difference in semantic or grammatical functions. What is more, its grammar rules seem more flexible than English ones. So, the learners always have difficulty in choosing the right words or grammar rules in the process of communication. They tend to have over-generalized errors in learning conjunctions, such as "erqiě" and "yě." In addition, they tend to ignore the limitations of the rules. Thus, they have many errors when learning to use Chinese conjunctions. Example 40 in "The blends of conjunctions in reversal relationship" is the case of this kind.

\section{Lack of Systematic Training}

Cohesion device is one of the most difficult techniques in Chinese learning. It is an important expression and application skill of Chinese, too. Therefore, grasping cohesion techniques requires special training. Due to factors, such as limited learning time, CSL learners are usually less trained in using cohesion devices. In view of this situation, more time should be assigned for the learners to have systematic training programs on using Chinese cohesion devices.

\section{Teaching Strategies}

How to improve the teaching method and effect of Chinese cohesion device is what many CSL teachers are researching. We provide our suggestions as following. 


\section{Teaching the CSL Learners to Learn the Thinking Mode of Chinese}

For those who have different cultural backgrounds and languages, their thinking modes are different too. Pan Wenguo (1997, pp. 359-340) and other scholars believe that the thinking mode of Westerners is straight while that of the oriental, especially the Chinese, is spiral. The Westerners lay stress on analysis while the Chinese on synthesis. The modes of thinking have effects on text cohesion device. Therefore, if the CSL learners want to solve the problem of text cohesion fundamentally, they must learn the thinking mode of Chinese, i.e., to think in Chinese.

\section{Cultivating the Learners' Contextual Concept of Chinese}

Only after having grasped a certain sense of context, CSL learners can build the power of language cohesion. In order to cultivate the learners' concept of context, the teachers should provide them with input corpus rich of textual devices, such as reference, ellipsis, conjunctions, run-on clauses, etc.. The teachers should lay emphasis on the communicative value of the corpus content, which can inspire the learner's interest. Moreover, the traditional way of teaching language is from small to large, which tends to have the defect of seeing the tree instead of the forest. We think that the teaching of Chinese cohesion devices to CSL learners should follow the strategy of teaching "from large to small". That is starting from the text, then moving down to the paragraph, to the sentences, to the clauses, and finally to the words and morphemes (Zhao, 2005).

\section{Comparing Similarities and Differences Between the Cohesion Devices of Mother-Tongue and Chinese}

It is necessary to compare the cohesion devices of mother-tongue and Chinese. The similar devices of the two languages can be taught through translation. The teachers should remind the learners to transplant the cohesion devices directly from the mother-tongue. The different devices of the two languages should be taught through comparison. Through doing comparison, the learners can have a clear picture of the differences between their mother-tongue and Chinese. Thus, they can reduce errors in the process of communication and promote the effect of acquisition (Zhao, 2005).

\section{Gradually Strengthening the Train of Writing for CSL Learners}

Usage of cohesion devices requires complicated training. Some scholars (Zhao, 2005) proposed that teaching textual cohesion to CSL learners should be from the "tangible" to the "invisible." From the "tangible" to the "invisible" means that the learners should firstly be guided to discover obvious signs of cohesion, such as conjunctions, and then be guided to learn those without signs, such as reference and substitution. Thus, programs should be designed to train the learners systematically in using Chinese cohesion devices. Only after sufficient training can the learners master gradually the techniques of text cohesion.

\section{Conclusion}

Chinese conjuctional devices are difficult for CSL learners, not only for the beginners, but also for those who have learned Chinese for over three years. So, the teachers should put emphasis on the learning and use of them. The key techniques to use them is to understand the relations simblized by the conjunctions, namely, parallel relationship, temporal succession, causal relationship, and reversal relationship. Then, much practice is required to grasp the use of Chinese conjunctional devices. Only through enough practice, can CSL learners use them freely and correctly. 


\section{References}

Ellis, R. (1994). The second language acquisition. England: Oxford University Press.

Halliday, M. A. K., \& Hasan, R. (1976). Cohesion in English. London: Longman.

James. C. (1998). Errors in language learning and uses: Exploring error analysis. London: Routledge.

Liao, Q. Z. (1991). The collection Liao Qiuzhong's thesis. Beijing: Beijing Language and Culture University Press.

Pan, W. G. (1997). An outline of Chinese-English contrastive study. Beijing: Beijing Language and Cultural University Press.

Qi, H. Y. (2005). Teaching Chinese as a foreign language. Shanghai: Fudan University Press.

Zhang, B. (2002). Modern Chinese. Shanghai: Fudan University Press.

Zhang, J. J. (2017). An analysis of the errors in the logical connection of Chinese narrative: A case study of senior CSL learners' writing in Henan University (M.A. thesis, Zhongshan University).

Zhao, C. X. (2005). An analysis of Chinese textual cohesion errors by CSL learners. Journal of Taizhou University, $2,49-51$.

Zheng, G. Y. (2002). Chinese textual linguistics. Beijing: Beijing Foreign Language Press.

Zhou, G. (2002). Conjunction and related issues. Hefei: Anhui Education Press. 